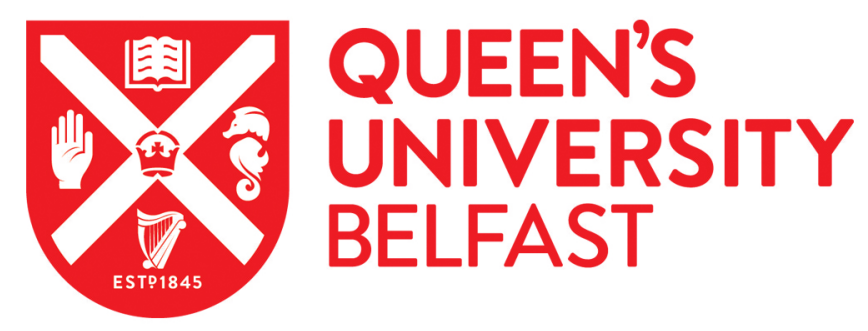

\title{
The Views and Experiences of Fathers of Children with Intellectual Disabilities: A Systematic Review of the International Evidence
}

Marsh, L., Brown, M., \& Mccann, E. (2020). The Views and Experiences of Fathers of Children with Intellectual Disabilities: A Systematic Review of the International Evidence. Journal of Policy and Practice in Intellectual Disabilities. https://doi.org/10.1111/jppi.12328

Published in:

Journal of Policy and Practice in Intellectual Disabilities

Document Version:

Peer reviewed version

Queen's University Belfast - Research Portal:

Link to publication record in Queen's University Belfast Research Portal

Publisher rights

( 2020 International Association for the Scientific Study of Intellectual and Developmental Disabilities and Wiley Periodicals, Inc. This work is made available online in accordance with the publisher's policies. Please refer to any applicable terms of use of the publisher.

\section{General rights}

Copyright for the publications made accessible via the Queen's University Belfast Research Portal is retained by the author(s) and / or other copyright owners and it is a condition of accessing these publications that users recognise and abide by the legal requirements associated with these rights.

Take down policy

The Research Portal is Queen's institutional repository that provides access to Queen's research output. Every effort has been made to ensure that content in the Research Portal does not infringe any person's rights, or applicable UK laws. If you discover content in the Research Portal that you believe breaches copyright or violates any law, please contact openaccess@qub.ac.uk. 


\title{
The views and experiences of fathers of children with intellectual disabilities: A systematic review of the international evidence
}

\begin{abstract}
As a result of societal changes and expectations, mothers have returned to paid employment, with fathers now more involved in the daily lives of their children with and without disabilities. Globally, fathers are providing more care for their children with intellectual disabilities (ID), a role traditionally expected of mothers. The research interest in the role of fathers in the lives of their child with ID is growing, yet much of the wider evidence has focused on the views and experiences of mothers as care givers. The aim of this systematic review was to identify the views and experiences of fathers parenting children with ID. A total of 14 studies were included in the review. Four themes were identified including emotional impact, mental health and coping, systems of support and hopes and fears. There is a need for further research on the needs of fathers and how they can be supported to play a fuller role in the lives of their child with ID. Implications for policy, practice and future research are also discussed.
\end{abstract}

Keywords: fathers, intellectual disability, systematic review, families, supports 


\section{Introduction}

There have been significant social changes in recent decades regarding families and the roles of mothers and fathers. The traditional role of care giving is no longer seen as the sole responsibility of mothers, with fathers now more fully involved with the care of their children (McGinnity \& Russell, 2013). To date, much of the evidence in the area of parenting has focused on the views and experiences of mothers' (Christopher, Umemura, Mann, Jacobvitz \& Hazen, 2015; Doss \& Rhoades, 2017), or a combination of mothers and fathers as care givers (Christopher et al., 2015; Coughlin, \& Sethares, 2017; Doss \& Rhoades, 2017) or a comparison of mothers' and fathers' experiences (Al-Yagon, 2015; McConnell \& Savage, 2015). Literature on the effects of being a father highlights that while the experience was often rewarding, the primary caring role continued to rest with mothers. While there is evidence that fathers' involvement with their children increases over time during the child's first year of life (Barry, Smith, Deutsch \& Perry-Jenkins, 2011), the coping abilities of, and parenting styles adopted within families, have been found to influence fathers' ability to adjust to his parenting role (Chin, Hall \& Daisches, 2011). Often, fathers' ability to be more fully involved was more challenging due to employment demands, challenging work patterns and financial implications (Craig \& Mullan, 2010).

Internationally, some governments have responded to the needs of families by putting in place legislation and policies regarding paternity rights. For example, in Nordic countries, Denmark, Finland, Iceland, Norway and Sweden, policies have been implemented that provide legal entitlement to paid paternity leave (Broberg, 2011; Haas \& Rostgaard, 2011). Since the 1970s, Sweden has implemented proactive social policy initiatives that enables both parents to share the 18 -month parental leave entitlement for each child. This policy has directly influenced and enabled shared child rearing and 
provided additional choice and flexibility (Broberg, 2011; Fägerskiöld, 2008). Now many countries such as the United Kingdom and Australia have parental leave policies in place, thereby recognising the role of fathers within the wider family context (Broomhill \& Sharp, 2012; Tanaka \& Waldfogel, 2007). Sweden has also extended financial support specifically to parents of children with disabilities (Olsson \& Hwang, 2006; Broberg, 2011). This affords the opportunity to focus on and respond to the needs of the child and provide caring activities in the early years (Olsson \& Hwang, 2006; Broberg, 2011). Yet, few countries make such provisions for parental leave specifically related to children with disabilities, a situation warranting further consideration.

The global increase in the population of children with ID living into adulthood who are now cared for at home has led to more fathers providing care for their children with ID (Caples, Martin, Dalton, Marsh, Savage, Knafl, \& van Riper, 2018; McKenzie, Milton, Smith \& Ouellette-Kuntz, 2016; Vacca, 2013; Willingham-Storr, 2014). Fathers are also caring for their children with complex health conditions requiring specific supports and interventions (Seliner, Latal \& Spirig, 2016), as well as for children presenting with significant behaviours that challenge (Rodas, Zeedyk, \& Baker, 2016). There is a well-developed and established body of evidence regarding the impact of having a child with ID on families and siblings (Chadwick, Mannan, Garcia-Iriarte, McConkey, O'Brien, Finlay, Lawlor \& Harrington, 2013; Shin, Nhan, Crittenden, Hong, Flory, \& Ladinsky, 2006). This evidence highlights that having a child with ID impacts upon the whole family, including siblings, and is in many cases positive (Fernández-Alcántara, Correa-Delgado, Muñoz, Salvatierra, Fuentes-Hélices, \& Laynez-Rubio, 2017; Horsley \& Oliver, 2015; Hastings, 2016).

The presence of a child with ID may enrich the family and can bring experiences of joy and pride (Nurullah, 2013; Dyches et al., 2012). However, for some families, 
there are issues related to initial shock and adjustment, stigma and coping with negative attitudes, the effects on siblings, sleeplessness, relationship strain and financial and employment implications (Cantwell, Muldoon \& Gallagher, 2015; Hayes \& Watson, 2013; Roper, Allred \& Mandleco, 2014; Saunders, Tilford \& Fussell, 2015). From the perspective of mothers', experiences are often positive (Horsley \& Oliver, 2015). However, some report anxiety and distress, lack of partner support, loss of employment with financial consequences and ability to respond effectively to the needs of siblings (Fairthorne, de Klerk \& Leonard, 2015). While there has been a focus on families and mothers', there has been less attention on the issues and concerns experienced by fathers' of children with ID, an assertion made by Hornby in 1994 in a review and analysis concerning fathers of children with disabilities.

\section{Method}

The aim of this literature review was to identify the specific needs, experiences and concerns of fathers' as a parent of a child with ID to inform future policy initiatives and guide future practice.

The review included peer reviewed and empirical studies of fathers of children with ID. A child was defined as someone under the age of 18 (Scottish Government, 2014). Studies regarding fathers' experiences of caring for a child with ASD were excluded due to the differing needs of fathers of adult children with ID or children with ASD. Care settings included home, residential, looked after and accommodated, respite or shared parenting were included in the review. Empirical studies that utilised qualitative, quantitative and mixed methods approaches were considered for inclusion.

\section{Ethics statement}


The study is a systematic review of published peer reviewed academic papers therefore ethical approval was not a requirement.

\section{Search and selection strategy}

A subject Librarian linked to the university provided expert guidance with the literature search strategy. Databases accessed were PsycINFO, CINAHL, MEDLINE, and Academic Search Complete. An example of the search process used in one electronic database is contained in Table 1.

***Insert Table 1 here***

Papers were published from December 1998 to December 2018 and included studies exclusively addressing the needs, experiences and concerns of fathers of children with ID. Studies that did not meet the criteria were excluded. The searches resulted in 598 hits across databases. A flow chart (Figure 1) contains the results of the searches (Moher, Shamseer, Clarke, Ghersi, Liberati, \& Petticrew et al., 2015).

***Insert Figure 1 here***

The inclusion criteria for the searches were limited to peer review and empirical studies in academic journals and written in English. Studies were searched by title and abstract and then full texts were examined against the inclusion criteria. A hand search was also conducted of the reference lists with one further paper identified. A total of 14 papers were finally included in the review.

\section{Quality assessment}


A quality assessment instrument was used as a framework to review the selected papers that were relevant in addressing the research question (Critical Appraisal Skills Programme, 2013). A series of ten questions was systematically applied to each paper so that papers could be judged in terms of trustworthiness, value and relevance as applied to the views and experiences of fathers of children with ID (see Table 2). Each reviewer scored the papers independently addressing the following questions; was there a clear statement of aims? Was an appropriate methodology, research design, recruitment strategy, and data collection method used? Was the research relationship and ethical considerations made explicit? Was the analysis rigorous and were findings clearly articulated? Finally, did the research add to the wider body of research, i.e. was it of value in shedding light on fathers' experiences? Each question was then scored zero, one or two. If a score of zero was attained, the paper had no information on that specific question, one if there was some information presented, and two points if the question was addressed comprehensively (Rushbrooke, Murray \& Townsend, 2014). An overall maximum score of 20 points could be achieved. A score of 17 and above, demonstrated a high-quality study, which was achieved in 11 of the studies. Three of the studies scored 16, indicating limitations in aspects related to the study aims, data collection methods, consideration of the research relationships and ethical considerations.

***Insert Table 2 here ***

\section{Characteristics of the studies}

The 14 studies that addressed the study aim are presented in Table 3. Studies were conducted in Australia $(n=1)$, Ireland $(n=2)$, Israel $(n=2)$, Japan $(n=1)$, Poland $(n=1)$, Sweden $(n=3)$, Taiwan $(n=1)$, United Kingdom $(n=2)$ and the United States of America (USA) (n=1). Sample sizes ranged from 7 (Boström \& Broberg, 2014) to 413 
(Huang, Chang, Chi, \& Lai, 2014) participants involving fathers of children with ID, including one study with a large control group of 203 participants (Huang, et al., 2014). A number of data collection methods were used in the studies including surveys, questionnaires and interviews. A total of five studies were qualitative (Boström \& Broberg, 2014; Carpenter \& Towers, 2008; Huang et al., 2011; Huang et al., 2012; Marsh et al., 2018) and nine studies were quantitative (Al-Yagon, 2011a; Al-Yagon, 2011b; Cohen et al, 2016; Dąbrowska, 2008; Giallo et al, 2016; Huang et al, 2014; MacDonald \& Hastings, 2010; MacDonald et al., 2010; Takataya et al., 2016).

***Insert Table 3 here ***

\section{Data extraction and analysis}

In conducting the systematic review, a process for synthesizing mixed literature sources were applied resulting in a thematic analysis of the data (Popay, Roberts \& Sowden, 2006). Once papers were read and re-read in full and scrutinised, each reviewer using an inductive approach systematically identified emergent and significant themes across all studies to address the aims of the review. Following the identification of themes, the three reviewers then discussed, cross checked and verified the themes. Subsequent coding allowed for contrasts and comparisons to be made between themes and studies until a consensus was reached (Caldwell, Henshaw \& Taylor, 2011).

\section{Findings}

Following the systematic and thematic analysis of the 14 studies, four themes were identified: (i) emotional consequences (ii) mental health and coping (iii) systems of support and (iv) hopes and fears for the future. 


\section{Emotional consequences}

Acknowledging fathers' in their role as care givers as well as recognising the emotional impact of a child's disability was highlighted across several studies (Carpenter \& Towers, 2008; Marsh et al., 2018; Takataya et al., 2016).

Fathers' anticipated the birth of a typically developing child and found themselves unprepared for the diagnosis of their child's ID (Marsh et al., 2018; Takataya et al., 2016). Once the child's diagnosis was confirmed, fathers' experienced diverse emotions from shock and disappointment, to grief and loss and denial and blame (Carpenter \& Towers, 2008; Marsh et al., 2018; Takataya et al., 2016). Irrespective of how and when the diagnosis of ID was received, fathers' had a variety of reactions to the child's disability with emotional responses initially being negative, but changing and becoming more positive over time (Boström \& Broberg, 2014; Marsh et al., 2018; Takataya et al., 2016).

Findings across studies also identified other factors that impacted on fathers' emotional well-being such as the risk of death of the child at birth due to serious health complications associated with a diagnosis of Down Syndrome (Takataya et al., 2016) and the timing of the diagnosis of the child's disability which when delayed compounded feelings of blame and guilt (Boström \& Broberg, 2014; Marsh et al., 2018).

Other findings indicated that a poor or inaccurate diagnosis of the ID by healthcare professionals as perceived by fathers' often resulted in poor care management for the child (Huang et al., 2011). In some cases, fathers' blamed themselves for not recognising the child's ID due to the presentation being unfamiliar to them, for example, global developmental delay or autism spectrum disorder, further 
delaying the diagnosis confirmation (Marsh et al., 2018). This resulted in a delay for the children accessing appropriate care, which was a significant concern for fathers. While Taiwanese fathers' wanted to 'keep hope alive,' and celebrate the birth of their child with ID, yet they found that healthcare professionals had difficulty with this concept, which could be attributed to the cultural stigma in Taiwan associated with being a parent of a child with ID. Fathers also expressed the need for healthcare professionals to improve and support family-centred care that is inclusive of fathers (Huang et al., 2012).

\section{Mental health and coping}

Several studies in the current review highlighted mental health issues that emerged for fathers of a child with ID and identified challenges that fathers experienced around adaptation, coping responses and acceptance (Al-Yagon, 2011a; Al-Yagon, 2011b; Cohen et al, 2016; Dąbrowska, 2008; Huang et al., 2014; MacDonald et al 2010). Fathers of children with ID when compared to fathers of children without ID, reported that they had experienced poor physical and mental health which they attributed to being fathers of a young child with ID (Huang et al., 2014). However, for some, a range of coping strategies such as information seeking and problem solving utilised by fathers had a positive and beneficial effect on their mental health (Al-Yagon, 2011a; Giallo et al., 2016). Active coping processes and lower levels of avoidance had a positive outcome on fathers' mental health and benefited the children in terms of adjustment and attachment (Al-Yagon, 2011a). There were also more positive gains, less stress and fewer symptoms of anxiety and depression experienced by fathers of children when acceptance was present (MacDonald et al 2010). Fathers expressed the need for the provision of more support and self-help to enable the development of positive child and 
father relationships, thereby improving mental health (Al-Yagon, 2011b). Positive mental health experiences were linked to practicing mindfulness, which, for some fathers, resulted in more active involvement in child-related parenting tasks and child socialization. The perceived benefits were evident for the father, child and family (MacDonald \& Hastings, 2010).

While some fathers reported satisfactory mental health, 6-8 per cent experienced 'severe' or 'extremely severe' levels of depression, anxiety and stress (Giallo et al., 2016), persisting as the child increased in age (Cohen et al., 2016). Other risk factors identified as adversely affecting fathers' mental health included: the additional care associated with parenting a child with ID; the child's behaviours; poor sleep patterns; less time available to relax, unwind, and for self; balancing family life and work life; and worries about the future (Cohen et al, 2016; Dąbrowska, 2008; Giallo et al., 2016; MacDonald et al 2010). Additionally, negative attitudes, perceptions and assumptions by healthcare professionals, family members and the public, regarding the roles and responsibilities of being a father of a child with an ID, also contributed to fathers' poor mental health experiences (Huang et al., 2014; Takataya et al., 2016). Some fathers reported that the child's behaviours rather than the child's disability per se, negatively affected their mental health. A number of the studies recognised the importance of educating fathers about the risk factors associated with deteriorating mental health and the provision of interventions to raise self-awareness and promotion of positive mental health (Al-Yagon, 2011a; Al-Yagon, 2011b; Cohen et al, 2016; Dąbrowska, 2008; Giallo et al., 2016; Huang et al., 2014).

\section{Systems of support}


The most common system of positive support reported by fathers were their partners (Cohen et al., 2016; Huang et al., 2011; Takataya et al., 2016). Support from partners was seen as beneficial by assisting fathers to share their experiences and worries. This increased the ability to cope with being a parent of a child with ID, leading to a reduction in anxiety and depression (Cohen et al., 2016). Accessing external supports such as counselling and support groups were viewed by some fathers as beneficial to developing coping skills (Cohen et al., 2016). Systems of external supports from healthcare professionals were viewed less positively (Carpenter \& Towers, 2008; Huang et al., 2011; Takataya et al., 2016). Some fathers felt excluded from the care of their child by some education and healthcare professionals rather than included.

This limited their sense of involvement and understanding of the education and healthcare being provided and the decision-making processes and outcomes (Carpenter \& Towers, 2008; Huang et al., 2011; Takataya et al., 2016). Taiwanese fathers felt excluded from decisions regarding their child's healthcare, experiencing poor communication and information sharing, an issue also reported by Japanese fathers (Huang et al., 2011; Takataya et al., 2016). A recurring issue across some studies was the need for education by healthcare professionals and educators to improve supports, information sharing and communication with fathers (Boström \& Broberg, 2014; Carpenter \& Towers, 2008; Dąbrowska, 2008; Huang et al., 2011; Takataya et al., 2016).

\section{Hopes and fears for the future}

Becoming a father of a child with ID was distressing and upsetting for many fathers, as it was a new and unexpected event, with little or no prior knowledge or experience to draw upon (Boström \& Broberg, 2014; Marsh et al., 2018; Takataya et 
al., 2016). Fathers focused on the immediate and long-term survival of their child and the desire to provide protection and strive to be a 'good' parent. Fears for the long-term future were associated with fathers own mortality, who would be best placed to care for their child in adulthood and where and whom their adult child would live in the future whom (Boström \& Broberg, 2014; Takataya et al., 2016). Concerns also existed regarding the degree of visibility and invisibility of the child's ID and possible consequences due to wider societal attitudes which were often negative as well as cultural expectations (Huang et al., 2012; Takataya et al., 2016).

Fathers highlighted their changing hopes for the future and the need to access supports from a range of professionals for this to be a reality (Boström \& Broberg, 2014; Huang et al., 2012; Takataya et al., 2016).

Seeking to protect the child from the consequences of negative attitudes and encounters with family, friends and professionals was also a concern for some (Takataya et al., 2016). Being a 'good' father was associated with accessing supports and seeking early assistance to support the child to achieve their developmental milestones and long-term independence (Al-Yagon, 2011a; Carpenter \& Towers, 2008). Some fathers had a realisation of the need to protect their own health to enable them to fulfil the role as a main care giver across the child's life and on into adulthood (Boström \& Broberg, 2014; Takataya et al., 2016).

\section{Discussion}

There have been significant changes in the composition of the traditional family over recent decades. What has evolved are diverse families that now take many shapes and forms. These changes have been influenced by a range of factors, including, state legislation and policies, gender differences, same-sex couples and single parents, which 
may include fathers of children with ID (Golombok, 2015). Additionally, as the number of premature neonates and children with ID increases, many with a range of complex and interrelated education, health and social care support needs, there is a need to ensure that the contributions of families in all their forms, including fathers, are realised and supported (Jarjour, 2015; O’Halloran, Sweeney, \& Doody, 2013; Thompson, HiebertMurphy \& Trute, 2013).

In response, this systematic review of the international research evidence was conducted and identified the views and experiences of fathers' parenting children with ID and included the emotions associated with the disclosure of a child's intellectual impairment, how fathers viewed their own mental health and responded and coped as fathers, the systems of support available and their hopes and fears for the future. Thereby, developments in terms of policy, practice and future research are further considered.

\section{Policy}

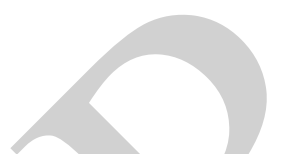

A recurring issue across studies included in this review of fathers is the need for professionals to recognise and respond to specific needs of fathers. There is therefore an opportunity for national and local policies to be fully reflective and responsive to their needs. Addressing their concerns will enable education, health and social care policies to be developed that more effectively target the specific support needs of fathers and ensure that these are met. Specific mental health and primary care policies must also take account of and respond to the mental health concerns and issues that fathers' experience. This is necessary to address specific mental health issues such as depression and anxiety, thereby promoting and enhancing coping-skills and resilience (Al-Yagon, 2011b; Cohen et al, 2016; Dąbrowska, 2008; Huang et al., 2014; 
MacDonald et al 2010). A useful development that has been established in Ireland is practice guidelines regarding the disclosure of a child's disability to families. The guidelines reflect the concerns of families, including fathers, and are built around seven best practice statements that aim to comprehensively address their needs (Hartnett, 2007).

Many governments provide paid statutory paternity leave as part of their social welfare system. Positive examples exist in Nordic and other countries that can be replicated more widely (Broberg, 2011; Broomhill \& Sharp, 2012; Haas \& Rostgaard, 2011; Tanaka \& Waldfogel, 2007). While such paid statutory paternity leave is important for families, there is also a need to ensure that barriers that may inhibit fathers from being fully involved in the care of their child with ID are fully recognised and addressed. From the findings from this review, social policy developments are required that offer families flexibility to adapt and respond to their evolving and changing family circumstances.

The Swedish welfare system provides financial support to parents of children with disabilities that allows them to focus on meeting their child caring activities, particularly in the early years (Broberg, 2011; Olsson \& Hwang, 2006). Thus, supporting fathers and their families financially and providing flexibility to increase involvement of working fathers with their children with ID is necessary given the additional workload associated with their care giving roles and responsibilities.

\section{Practice}

An area requiring a practice focus relates to the education and development of professionals working with and supporting families and fathers of children with ID. This is necessary as fathers' expressed concerns about their level of involvement and 
engagement in decisions regarding their child, for example regarding education and healthcare decisions. Establishing and maintaining open and effective communication is essential to ensure their needs and concerns are recognised and responded to appropriately. Therefore, there is the opportunity for professionals to engage and form alliances with fathers and to work collaboratively to effectively meet the holistic needs of fathers and their families (Carpenter \& Towers, 2008; Huang et al., 2012; Takataya et al., 2016).

Access to social support and networks is another area requiring attention and development. At present support is provided predominately by partners, with the need for dedicated counselling and support targeted at fathers as a gap in current provision is evident (Cohen et al., 2016; Huang et al., 2011; Takataya et al., 2016). Such support networks have the potential to provide fathers with access to peer support and the opportunity to share experiences and learn from each other.

From a therapeutic perspective, mindfulness was identified as a potentially useful intervention for fathers (MacDonald \& Hastings, 2010). Other studies support the use of mindfulness approaches and discovered that training parents led to improved parental satisfaction and enhanced parent-child interactions (Chapman, Hare, Caton, Donalds, McInnis \& Mitchell, 2013).

By drawing on and integrating the evidence of the needs and concerns of fathers, there is an opportunity for shared inter-professional learning and practice development across professional disciplines, such as nursing, social work, education, child services, primary care and specialist disability services. Involving fathers in the co-production, design and delivery of education programmes offers an opportunity to ensure that their experiences and expertise are reflected and included. Their personal experiences can provide valuable and powerful learning opportunities and develop the understanding of 
the concerns of fathers and their family. From the perspective of undergraduate and postgraduate education, there is also a need to ensure that the specific family and father issues and concerns are integrated within programmes, thereby reflecting their hopes and aspirations as well as highlighting their challenges and support requirements.

\section{Strengths and limitations}

This review has identified important areas that require a policy focus and developments in practice and education. This is important to ensure that the needs of fathers, children with ID and their families are effectively identified and met. Some limitations of this review was that no intercultural, national or international multi-centre research studies were identified, therefore, there is scope to undertake larger projects involving different geographical areas and countries. In addition, the available evidence in this review comprised of small-scale, single site studies. There was also had a lack of intervention and outcome focused studies in this review such as psychoeducation and support programmes specific to the needs of fathers. Throughout the review process, the authors sought to be rigorous and acknowledge the potential for subjectivity.

\section{Future research}

This review provides a detailed analysis of the current evidence base regarding fathers of children with ID. The review identifies the need for research in this area to increase and develop knowledge and understanding of the specific needs of fathers and their families. There is an absence of research specifically focusing on policy and its 
implementation and outcomes. There is also a lack of intervention studies addressing the role and contribution of fathers within the context of the family, siblings, and the needs of the child with ID. This may include psychoeducation programmes, specific family intervention work and quality of life studies. While this review focused exclusively on the views and experiences of fathers' as parents, the views of mothers and fathers together as parents are equally as important. The views and experiences of all family members and those who are significant in the life and care of a child with ID, must be considered in policy, practice and future research. Future research which is inclusive of the views and experiences of all of people who are significant would be beneficial in identifying specific needs in relation to being a parent of a child with ID.

\section{Conclusion}

The existing evidence highlights that fathers are taking on caring roles and responsibilities for their child with ID which can be both rewarding and challenging. Recognition of the important place of fathers in the lives of their child with ID is important and responding to their distinct support needs is essential to maximise and strengthen their contribution to their family. There is an opportunity for the voices of fathers' to be more widely reflected and included in national and local policies and strategies, thereby influencing and shaping societal attitudes so that they can focus on the rewards and satisfaction of being a father. While professionals have important contributions to make in supporting fathers, their children and families, there are specific areas of practice and education that require attention and development to respond more effectively. The subject of the distinct experiences and needs of fathers' presents an important area for further national and international research. 


\section{Conflict of interest}

The authors declared no conflict of interest 


\section{References}

Al-Yagon, M. (2011a). Fathers' coping resources and children's socioemotional adjustment among children with learning disabilities. Journal of Learning Disabilities 44(6), 491-507.

Al-Yagon, M. (2011b). Fathers' emotional resources and children's socioemotional and behavioral adjustment among children with learning disabilities. Journal Child \& Family Studies 20, 569-584.

Al-Yagon, M., (2015). Fathers and mothers of children with learning disabilities: Links between emotional and coping resources. Learning disability quarterly, 38(2), 112-128.

Barry, A.A., Smith J., Deutsch, F. \& Perry-Jenkins, M. (2011). Fathers' involvement in child care and perceptions of parenting skill over the transition to parenthood. Journal of Family Issues 32(11), 1500-1521.

Boström, P.K. \& Broberg, M. (2014). Openness and avoidance - a longitudinal study of fathers of children with intellectual disability. Journal of Intellectual Disability Research 58(9), 810-821.

Broberg, M. (2011). Expectations of and reactions to disability and normality experienced by parents of children with intellectual disability in Sweden. Child: care, Health and Development 37(3), 410-417.

Broomhill, R. \& Sharp, R. (2012). Australia's parental leave policy and gender equality: an international comparison. Australian Workplace Innovation and Social Research Centre: The University of Adelaide.

Caldwell, K., Henshaw, I. \& Taylor, G. (2011). Developing a framework for critiquing health research: An early evaluation. Nurse Education Today 31(8), 1-7.

Cantwell, J., Muldoon, O., \& Gallagher, S. (2015). The Influence of Self-Esteem and Social Support on the Relationship between Stigma and Depressive Symptomology in Parents Caring for Children with Intellectual Disabilities. Journal of Intellectual Disability Research 59, 948-957.

Caples, M., Martin, A.M., Dalton, C., Marsh, L. Savage, E. Knafl, G. \& van Riper, M. (2018). Adaptation and resilience in families of individuals with Down syndrome living in Ireland. British Journal of Learning Disabilities 3(46); 146-154.

Carpenter, B. \& Towers, C. (2008). Recognising fathers: The needs of fathers of children with disabilities. Support for Learning 23, 118-25.

Chadwick, D.D., Mannan, H., Garcia-Iriarte E., McConkey, R., O'Brien, P., Finlay, F., Lawlor, A. \& Harrington, G. (2013) Family Voices: Life for Family Carers of People with Intellectual Disabilities in Ireland. Journal of Applied Research in Intellectual Disabilities 26(2), 119-132. 
Chapman, M. J., Hare, D. J., Caton, S., Donalds, D., McInnis, E., \& Mitchell, D. (2013). The use of mindfulness with people with intellectual disabilities: A systematic review and narrative analysis. Mindfulness 4(2), 179-189.

Christopher, C., Umemura, T., Mann., Jacobvitz, D. \& Hazen, N. (2015). Marital Quality over the Transition to Parenthood as a Predictor of Coparenting. Current Opinion in Psychology 13(12), 3636-3651.

Cohen, S.R., Zeedyk, S.M., Tipton, L.A., Rodas, N.V., \& Blacher, J. (2016) Fathers of children with or without ID: Understanding longterm psychological symptoms. Journal of Intellectual Disability Research 60(4), 295-307.

Coughlin, M.B. and Sethares, K.A., (2017). Chronic sorrow in parents of children with a chronic illness or disability: an integrative literature review. Journal of Pediatric Nursing 37, 108-116.

Chin R., Hall, P. \& Daiches A. (2011). Fathers' experiences of their transition to fatherhood: a metasynthesis. Journal of Reproductive and Infant Psychology 29(1), 418.

Craig, L. \& Mullan, K. (2010). Parenthood, Gender and Work-Family Time in the United States, Australia, Italy, France, and Denmark. Journal of Marriage and Family 72(5), 1344-1361.

Critical Appraisal Skills Programme (2013). Ten questions to help you make sense of qualitative research. Critical Appraisal Skills Programme, Oxford.

Dąrowska, A. (2008). Sense of coherence and coping with stress in fathers of children with developmental disabilities. Polish Psychological Bulletin 39(1), 29-34.

Doss, B.D. \& Rhoades, G.K. (2017). The transition to parenthood: impact on couples' romantic relationships. Current Opinion in Psychology 13; 25-28.

Dyches, T.T., Smith, T.B., Korth, B.B., Roper, S.O.\& Mandleco, B. (2012). Positive parenting of children with developmental disabilities: a meta-analysis. Research Developmental Disabilities 33(6), 2213-20

Fägerskiöld, A. (2008). A change in life as experienced by first-time fathers. Scandinavian Journal of Caring Sciences 22(1), 64-71.

Fairthorne, J., De Klerk, N. \& Leonard, H. (2015). Health of mothers of children with intellectual disability or autism spectrum disorder: A review of the literature. Medical Research Archives 1-3.

Fernández-Alcántara, M., Correa-Delgado, C., Muñoz, Á., Salvatierra, M.T., FuentesHélices, T. \& Laynez-Rubio, C. (2017). Parenting a Child with a Learning Disability: A Qualitative Approach. International Journal of Disability, Development and Education 64(5), 526-543. 
Giallo, R., Seymour, M., Matthews, J., Gavidia-Payne, S., Hudson., A. \& Cameron, C. (2015). Risk factors associated with the mental health of fathers of children with an intellectual disability in Australia. Journal of Intellectual Disability Research 59(3), 193-207.

Golombok, S. (2015). Modern families: Parents and children in new family forms. Cambridge: Cambridge University Press.

Haas, L. \& Rostgaard, T. (2011). Fathers' rights to paid parental leave in the Nordic countries: consequences for the gendered division of leave. Community, Work \& Family 14(2), 177-195.

Hartnett, A. (2007). Informing families of their child's disability. National Best Practice Guidelines. National Federation of Voluntary Bodies.

http://www.fedvol.ie/_fileupload/File/Informing\%20Families\%20Guidelines.pdf

Hastings, R.P. (2016). Do Children With Intellectual and Developmental Disabilities Have a Negative Impact on Other Family Members? The Case for Rejecting a Negative Narrativea. In International Review of Research in Developmental Disabilities 50, 165-194).

Hayes, S.A., \& Watson, S.L. (2013). The Impact of Parenting Stress: A Meta-analysis of Studies Comparing the Experience of Parenting Stress in Parents of Children With and Without Autism Spectrum Disorder. Journal of Autism and Developmental Disorders 43, 629-642

Hornby, G. (1994). Effects of children with disabilities on fathers: A review and analysis of the literature. International Journal of Disability, Development and Education 41(3), 171-184.

Horsley, S. \& Oliver, C. (2015). Positive impact and its relationship to well-being in parents of children with intellectual disability: a literature review, International Journal of Developmental Disabilities 61(1), 1-19.

Huang, Y.P., Tsai, S.W. \& Kellett, U. (2011). Fathers of children with disabilities: encounters with health professionals in a Chinese context. Journal of Clinical Nursing 21, 198-206.

Huang, Y.P., Chen, S.L. \& Tsai, S.W. (2012). Father's experiences of involvement in the daily care of their child with developmental disability in a Chinese context.

Journal of Clinical Nursing 21, 3287-3296.

Huang, Y.P., Chang, M., Chi, Y.L. \& Lai, F.C. (2014). Health-related quality of life in fathers of children with or without developmental disability: the mediating effect of parental stress. Quality of Life Research 23, 175-183.

Jarjour, I. T. (2015). Neurodevelopmental outcome after extreme prematurity: A review of the literature. Pediatric Neurology 52(2), 143-152. 
MacDonald, E. \& Hastings, R.P. (2010). Mindful Parenting and Care Involvement of Fathers of Children with Intellectual Disabilities. Journal of Child \& Family Studies 19, 236-240.

MacDonald, E. Hastings, R.P. \& Fitzsimons, E. (2010). Psychological Acceptance Mediates the Impact of the Behaviour Problems of Children with Intellectual Disability on Fathers' Psychological Adjustment. Journal of Applied Research in Intellectual Disabilities 23, 27-37.

McConnell, D. \& Savage, A., (2015). Stress and resilience among families caring for children with intellectual disability: expanding the research agenda. Current developmental disorders reports 2(2), 100-109.

Marsh, L., Leahy-Warren, P. \& Savage, E. (2018). "Something was wrong": A narrative inquiry of becoming a father of a child with an intellectual disability in Ireland. British Journal of Learning Disabilities 46, 216-224.

McGinnity, F., \& Russell, H. (2013). Work-family conflict and economic change. Economic crisis, quality of work and social integration: The European Experience, 169-194.

McKenzie, K., Milton, M., Smith, G., \& Ouellette-Kuntz, H. (2016). Systematic review of the prevalence and incidence of intellectual disabilities: current trends and issues. Current Developmental Disorders Reports 3(2), 104-115.

Moher, D., Shamseer, L., Clarke M., Ghersi, D., Liberati, A., Petticrew, M,...... PRISMA-P Group (2015). Prefered reporting items for systematic review and metaanalysis protocols (PRISMA-P) 2015 statement. Systematic Reviews 4(1), 1-9.

Nurullah, A.S. (2013) "It's Really a Roller Coaster": Experience of Parenting Children with Developmental Disabilities. Marriage \& Family Review 49(5), 412-445.

O'Halloran, M., Sweeney, J. \& Doody, O. (2013). Exploring fathers' perceptions of parenting a child with Asperger syndrome. Journal of Intellectual Disabilities 17(3), 198-213.

Olsson M.B. \& Hwang C. (2006) Well-being, involvement in paid work and division of child-care in parents of children with intellectual disabilities in Sweden. Journal of Intellectual Disability Research 50(12), 963-969.

Popay, J., Roberts, H. \& Sowden, A. (2006). Guidance on the Conduct of Narrative Synthesis in Systematic Reviews: Final Report. Swindon: ESRC Methods Programme.

Rodas, N. V., Zeedyk, S. M., \& Baker, B. L. (2016). Unsupportive parenting and internalising behaviour problems in children with or without intellectual disability. Journal of Intellectual Disability Research 60(12); 1200-1211.

Roper, S. O., Allred, D. W., Mandleco, B., Freeborn, D., \& Dyches, T. (2014). Caregiver burden and sibling relationships in families raising children with disabilities and typically developing children. Families, Systems, \& Health 32(2); 241-246. 
Rushbrooke, E., Murray, C., \& Townsend, S. (2014). The experiences of intimate relationships by people with intellectual disabilities: A qualitative study. Journal of Applied Research in Intellectual Disabilities 27(6), 531-541.

Saunders, B.S., Tilford, J.M., Fussell, J.J., Schulz, E.G., Casey, P.H., \& Kuo, D.Z. (2015). Financial and employment impact of intellectual disability on families of children with autism. Families, Systems \& Health: The Journal of Collaborative Family Healthcare 33(1), 36-45.

Scottish Government (2014). National Guidance for Child Protection in Scotland. Scottish Government. https://www2.gov.scot/Resource/0045/00450733.pdf

Seliner, B., Latal, B., \& Spirig, R. (2016). When children with profound multiple disabilities are hospitalized: A cross-sectional survey of parental burden of care, quality of life of parents and their hospitalized children, and satisfaction with familycentered care. Journal for Specialists in Pediatric Nursing 21(3), 147-157.

Shin, J., Nhan, N. V., Crittenden, K. S., Hong, H. T. D., Flory, M., \& Ladinsky, J. (2006). Parenting stress of mothers and fathers of young children with cognitive delays in Vietnam. Journal of Intellectual Disability Research 50(10), 748-760.

Takataya, K., Yamazaki, Y., \& Mizuno, E. (2016). Perceptions and feelings of fathers of children with Down syndrome. Archives of Psychiatric Nursing 30(5), 44-551.

Tanaka, S. \& Waldfogel J. (2007). Effects of Parental Leave and Work Hours On Fathers' Involvement With Their Babies. Community, Work \& Family 10(4), 409426.

Thompson, S., Hiebert-Murphy, D., \& Trute, B. (2013). Parental perceptions of family adjustment in childhood developmental disabilities. Journal of Intellectual Disabilities 17(1), 24-37.

Vacca, J.J. (2013). The Parenting Process from the Father's Perspective. Best Practices in Mental Health 9(2), 79-93.

Willingham-Storr, G.L. (2014). Parental experiences of caring for a child with intellectual disabilities: A UK perspective. Journal of Intellectual Disabilities 18(2), 146-158. 
Table 1: PsycINFO search results

\begin{tabular}{|l|l|l|}
\hline $\begin{array}{l}\text { Search } \\
\text { code }\end{array}$ & Query & Results \\
\hline S1 & father* & 47033 \\
\hline S2 & Child* & 716660 \\
\hline S3 & intellectual disab* & 14660 \\
\hline S4 & mental retard* & 29702 \\
\hline S5 & mental handicap & 744 \\
\hline S6 & developmental disab* & 15073 \\
\hline S7 & learning disab* & 26728 \\
\hline S8 & S3 OR S4 OR S5 OR S6 OR S7 & 72175 \\
\hline S9 & S1 AND S2 AND S8 & 580 \\
\hline S10 & $\begin{array}{l}\text { With Limiters: Years 1998-2018; } \\
\text { academic journals; English }\end{array}$ & 476 \\
\hline
\end{tabular}


Table 2: CASP quality scores

\begin{tabular}{|c|c|c|c|c|c|c|c|}
\hline CASP criteria & $\begin{array}{l}\text { Al-Yagon } \\
\text { (2011a) }\end{array}$ & $\begin{array}{l}\text { Al-Yagon } \\
\text { (2011b) }\end{array}$ & $\begin{array}{l}\text { Boström \& } \\
\text { Broberg } \\
(2014)\end{array}$ & $\begin{array}{l}\text { Carpenter \& } \\
\text { Towers (2008) }\end{array}$ & $\begin{array}{l}\text { Cohen et al. } \\
\text { (2016) }\end{array}$ & $\begin{array}{l}\text { Dąbrowska } \\
(2008)\end{array}$ & $\begin{array}{l}\text { Giallo et al. } \\
\text { (2016) }\end{array}$ \\
\hline 1. Clear statement of aims & 1 & 1 & 2 & 2 & 2 & 2 & 2 \\
\hline 3. Appropriate research design & 2 & 2 & 2 & 2 & 2 & 2 & 2 \\
\hline 4. Appropriate recruitment strategy & 2 & 2 & 2 & 2 & +2 & 2 & 2 \\
\hline 5. Appropriate data collection methods & 2 & 2 & 2 & 2 & 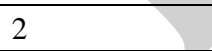 & 2 & 2 \\
\hline 7. Consider ethical issues & 2 & 2 & 2 & 0 & 2 & 0 & 2 \\
\hline 8. Rigorous analysis & 2 & 2 & 2 & 2 & 2 & 2 & 2 \\
\hline 9. Clear findings & 1 & 1 & 2 & 2 & 2 & 2 & 2 \\
\hline 10. Value of the research & 2 & 2 & 2 & 2 & 2 & 2 & 2 \\
\hline Total scores out of 20 & 16 & 16 & 18 & 17 & 20 & 16 & 18 \\
\hline CASP criteria & $\begin{array}{l}\text { Huang et al. } \\
\text { (2011) }\end{array}$ & $\begin{array}{l}\text { Huang et al. } \\
\text { (2012) }\end{array}$ & $\begin{array}{l}\text { Huang et al. } \\
\text { (2014) }\end{array}$ & $\begin{array}{l}\text { MacDonald \& } \\
\text { Hastings (2010) }\end{array}$ & $\begin{array}{l}\text { MacDonald et } \\
\text { al. (2010) }\end{array}$ & $\begin{array}{l}\text { Marsh et al. } \\
\text { (2018) }\end{array}$ & $\begin{array}{l}\text { Takataya et al. } \\
\text { (2016) }\end{array}$ \\
\hline 1. Clear statement of aims & 2 & 2 & 2 & 2 & 2 & 2 & 2 \\
\hline 2. Appropriate methodology & 2 & 2 & 2 & 2 & 2 & 2 & 2 \\
\hline 3. Appropriate research design & 2 & 2 & 2 & 2 & 2 & 2 & 2 \\
\hline 4. Appropriate recruitment strategy & 2 & 2 & 2 & 2 & 2 & 2 & 2 \\
\hline 5. Appropriate data collection methods & 2 & 2 & 2 & 2 & 2 & 2 & 2 \\
\hline 6. Research relationships considered & 0 & 0 & 0 & 2 & 2 & 1 & 2 \\
\hline 7. Consider ethical issues & 2 & 2 & 2 & 2 & 2 & 2 & 2 \\
\hline 8. Rigorous analysis & 2 & 2 & 2 & 2 & 2 & 2 & 2 \\
\hline 9. Clear findings & 2 & 2 & 2 & 2 & 2 & 2 & 2 \\
\hline 10. Value of the research & 2 & 2 & 2 & 2 & 2 & 2 & 2 \\
\hline Total scores out of 20 & 18 & 18 & 18 & 20 & 20 & 19 & 20 \\
\hline
\end{tabular}


Table 3: Papers included in the review

\begin{tabular}{|c|c|c|c|c|c|}
\hline $\begin{array}{l}\text { Study } \\
\text { Citation \& } \\
\text { Country }\end{array}$ & Aims & Sample & $\begin{array}{l}\text { Data collection } \\
\text { method }\end{array}$ & Key Findings & Recommendations \\
\hline $\begin{array}{l}\text { Al-Yagon } \\
(2011 \mathrm{a}) \\
\text { Israel }\end{array}$ & $\begin{array}{l}\text { Examine fathers' } \\
\text { coping resources } \\
\text { and children's } \\
\text { socioemotional } \\
\text { adjustment }\end{array}$ & $\begin{array}{l}\text { Fathers } \\
(\mathrm{n}=107)\end{array}$ & Questionnaires & $\begin{array}{l}\text { Children adjustment is improved when } \\
\text { fathers demonstrate higher levels of active } \\
\text { coping, information seeking, problem } \\
\text { solving and lower levels of avoidant } \\
\text { coping, including use of drugs and alcohol. }\end{array}$ & $\begin{array}{l}\text { Support fathers to recognise levels of } \\
\text { active coping and avoidance by } \\
\text { providing help to develop and } \\
\text { improve child and father } \\
\text { relationships. }\end{array}$ \\
\hline $\begin{array}{l}\text { Al-Yagon } \\
(2011 \mathrm{~b}) \\
\text { Israel }\end{array}$ & $\begin{array}{l}\text { Identify fathers' } \\
\text { emotional } \\
\text { resources and } \\
\text { children's } \\
\text { socioemotional } \\
\text { and behavioral } \\
\text { adjustment }\end{array}$ & $\begin{array}{l}\text { Fathers } \\
(n=107)\end{array}$ & Questionnaires & $\begin{array}{l}\text { Children with ID are adversely affected by } \\
\text { fathers who demonstrate lower levels of } \\
\text { active coping. }\end{array}$ & $\begin{array}{l}\text { Need to target fathers demonstrating } \\
\text { low levels of active coping and } \\
\text { avoidance and provide support and } \\
\text { self-help with child and father } \\
\text { relationships. Further qualitative } \\
\text { research required. }\end{array}$ \\
\hline $\begin{array}{l}\text { Boström \& } \\
\text { Broberg } \\
(2014) \\
\text { Sweden }\end{array}$ & $\begin{array}{l}\text { Explore fathers' } \\
\text { experiences of } \\
\text { parenting young } \\
\text { children with } \\
\text { intellectual and } \\
\text { developmental } \\
\text { disabilities (IDD) } \\
\text { from initial } \\
\text { diagnosis to } 5 \\
\text { years later }\end{array}$ & $\begin{array}{l}\text { Fathers } \\
(\mathrm{n}=7)\end{array}$ & $\begin{array}{l}\text { Semi-structured } \\
\text { interviews }\end{array}$ & $\begin{array}{l}\text { Fathers' reactions to their child's } \\
\text { diagnosis. Self-perception of parenting } \\
\text { their child. Father's adaptation to their } \\
\text { child's disability over the } 5 \text { years. }\end{array}$ & $\begin{array}{l}\text { Support for fathers should draw on } \\
\text { assets and strengths when offering } \\
\text { psychological support to families of } \\
\text { children with IDD. }\end{array}$ \\
\hline $\begin{array}{l}\text { Carpenter \& } \\
\text { Towers } \\
(2008)\end{array}$ & $\begin{array}{l}\text { Identify issues and } \\
\text { needs of fathers of } \\
\text { children with an }\end{array}$ & $\begin{array}{l}\text { Fathers } \\
(n=21)\end{array}$ & Interviews & $\begin{array}{l}\text { The emotional impact on fathers of having } \\
\text { a child with a learning disability. The roles } \\
\text { and responsibilities of fathers. Impact on }\end{array}$ & $\begin{array}{l}\text { Further research required with larger } \\
\text { cohorts of fathers to identify factors }\end{array}$ \\
\hline
\end{tabular}




\begin{tabular}{|c|c|c|c|c|c|}
\hline UK & $\begin{array}{l}\text { intellectual } \\
\text { disability }\end{array}$ & & & $\begin{array}{l}\text { the father's employment. Supports and } \\
\text { relationship between fathers and } \\
\text { practitioners. Concerns around the child's } \\
\text { developmental trajectory. }\end{array}$ & $\begin{array}{l}\text { that motivate and support them in } \\
\text { their parental role. }\end{array}$ \\
\hline $\begin{array}{l}\text { Cohen et al } \\
2016 \\
\text { USA }\end{array}$ & $\begin{array}{l}\text { Examine fathers' } \\
\text { perceptions } \\
\text { of their long-term } \\
\text { psychological } \\
\text { symptoms related } \\
\text { to their children's } \\
\text { behavioural issues }\end{array}$ & $\begin{array}{l}\text { Fathers } \\
(n=182)\end{array}$ & Questionnaires & $\begin{array}{l}\text { No changes identified regarding fathers' } \\
\text { psychological symptoms as children got } \\
\text { older. Children's behaviours affected } \\
\text { fathers' psychological well-being, with } \\
\text { spousal support reducing psychological } \\
\text { symptoms. }\end{array}$ & $\begin{array}{l}\text { Develop health practitioner's abilities } \\
\text { to support fathers of children with } \\
\text { behavioural challenges. A range of } \\
\text { external supports are required } \\
\text { including counseling and support } \\
\text { groups and the need to develop } \\
\text { working relationships with fathers }\end{array}$ \\
\hline $\begin{array}{l}\text { Dąbrowska } \\
\text { (2008) } \\
\text { Poland }\end{array}$ & $\begin{array}{l}\text { Investigate } \\
\text { relationships } \\
\text { between sense of } \\
\text { coherence and } \\
\text { coping with stress }\end{array}$ & $\begin{array}{l}\text { Fathers } \\
(n=123)\end{array}$ & Questionnaires & $\begin{array}{l}\text { Lower levels of global sense of coherence } \\
\text { is not associated with a being a father of a } \\
\text { child with ID. Fathers of children with } \\
\text { Down Syndrome demonstrated poorer } \\
\text { sense of meaningfulness compared to } \\
\text { fathers of children with autism. }\end{array}$ & $\begin{array}{l}\text { Need to have a better understanding } \\
\text { of coherence and stress to support } \\
\text { fathers more effectively. }\end{array}$ \\
\hline $\begin{array}{l}\text { Giallo et al. } \\
\text { (2016) } \\
\text { Australia }\end{array}$ & $\begin{array}{l}\text { Examine risk } \\
\text { factors associated } \\
\text { with fathers' } \\
\text { mental health }\end{array}$ & $\begin{array}{l}\text { Fathers } \\
(\mathrm{n}=315)\end{array}$ & & $\begin{array}{l}\text { Significantly more symptoms of } \\
\text { depression and stress reported in fathers. } \\
\text { Mental health risk factors include } \\
\text { children's behaviour problems, daily stress } \\
\text { arising from fathers' own needs and } \\
\text { children's care needs, and } \\
\text { low parenting satisfaction. }\end{array}$ & $\begin{array}{l}\text { Identifying other risk factors would } \\
\text { help fathers with mental health issues } \\
\text { as this identification could lead to } \\
\text { increased self-awareness. More } \\
\text { specific information and } \\
\text { interventions are required. }\end{array}$ \\
\hline $\begin{array}{l}\text { Huang et al. } \\
(2011) \\
\text { Taiwan }\end{array}$ & $\begin{array}{l}\text { Examine fathers' } \\
\text { experiences of } \\
\text { interactions with } \\
\text { health } \\
\text { professionals }\end{array}$ & $\begin{array}{l}\text { Fathers } \\
(\mathrm{n}=16)\end{array}$ & Interviews & $\begin{array}{l}\text { Significant communication problems } \\
\text { evident, including exclusion from } \\
\text { decision-making. Poor or incorrect } \\
\text { diagnosis impacted on the management of } \\
\text { child's disability. }\end{array}$ & $\begin{array}{l}\text { Fathers need to be included and } \\
\text { empowered by health practitioners as } \\
\text { partners in the care of their child. }\end{array}$ \\
\hline $\begin{array}{l}\text { Huang et al. } \\
\text { (2012) }\end{array}$ & $\begin{array}{l}\text { Explore fathers' } \\
\text { experiences of } \\
\text { involvement in the }\end{array}$ & $\begin{array}{l}\text { Fathers } \\
(n=16)\end{array}$ & $\begin{array}{l}\text { Semi-structured } \\
\text { interviews }\end{array}$ & $\begin{array}{l}\text { There is a need to encourage a sense of } \\
\text { hope and respond to issues regarding } \\
\text { quality of healthcare and focus on }\end{array}$ & $\begin{array}{l}\text { Nurses need to promote and support } \\
\text { fathers' involvement in child care to }\end{array}$ \\
\hline
\end{tabular}




\begin{tabular}{|c|c|c|c|c|c|}
\hline Taiwan & $\begin{array}{l}\text { care of children } \\
\text { with IDD }\end{array}$ & & & $\begin{array}{l}\text { improving and supporting family } \\
\text { functioning. }\end{array}$ & $\begin{array}{l}\text { develop their relationships and the } \\
\text { provide wider family benefits. }\end{array}$ \\
\hline $\begin{array}{l}\text { Huang et al. } \\
(2014) \\
\text { Taiwan }\end{array}$ & $\begin{array}{l}\text { Identify the } \\
\text { mediating effect of } \\
\text { parental stress on } \\
\text { children with and } \\
\text { without ID }\end{array}$ & 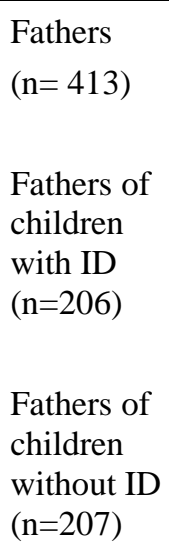 & Questionnaires & $\begin{array}{l}\text { Impact identified on the mental health of } \\
\text { fathers of children with ID. Fathers of } \\
\text { children with ID experienced poorer } \\
\text { physical and mental health, with higher } \\
\text { levels of stress. }\end{array}$ & $\begin{array}{l}\text { Health practitioners need to recognise } \\
\text { and respond to stress factors in } \\
\text { fathers of children with ID by using } \\
\text { supportive strategies and } \\
\text { interventions. }\end{array}$ \\
\hline $\begin{array}{l}\text { MacDonald } \\
\text { \& Hastings } \\
\text { (2010) } \\
\text { UK }\end{array}$ & $\begin{array}{l}\text { Investigate } \\
\text { mindful parenting } \\
\text { involvement of } \\
\text { fathers of children } \\
\text { with IDD }\end{array}$ & $\begin{array}{l}\text { Fathers } \\
(n=105)\end{array}$ & Surveys & $\begin{array}{l}\text { Fathers who reported being more mindful } \\
\text { had more involvement in child-related } \\
\text { parenting tasks and child socialisation. }\end{array}$ & $\begin{array}{l}\text { Mindfulness and acceptance-based } \\
\text { interventions may be beneficial to } \\
\text { parents that may impact } \\
\text { psychological distress and improved } \\
\text { parenting attributes. More evaluation } \\
\text { and outcome studies of mindfulness- } \\
\text { based interventions are needed. }\end{array}$ \\
\hline $\begin{array}{l}\text { MacDonald, } \\
\text { et al. (2010) } \\
\text { Ireland }\end{array}$ & $\begin{array}{l}\text { Investigate if the } \\
\text { child's behaviour } \\
\text { problems was } \\
\text { mediated by } \\
\text { fathers acceptance }\end{array}$ & $\begin{array}{l}\text { Fathers } \\
(n=99)\end{array}$ & Questionnaire & $\begin{array}{l}\text { Fathers who were accepting of their child } \\
\text { with IDD reported more positive gains, } \\
\text { less stress and fewer symptoms of anxiety } \\
\text { and depression. }\end{array}$ & $\begin{array}{l}\text { Mindfulness-based interventions may } \\
\text { be helpful in terms of parental } \\
\text { adjustment. } \\
\text { Need to understand that mothers and } \\
\text { fathers may differ in terms of their } \\
\text { parenting styles and needs. }\end{array}$ \\
\hline $\begin{array}{l}\text { Marsh et al. } \\
\text { (2018) } \\
\text { Ireland }\end{array}$ & $\begin{array}{l}\text { Examine the } \\
\text { experiences of } \\
\text { fathers' before and }\end{array}$ & $\begin{array}{l}\text { Fathers } \\
(\mathrm{n}=10)\end{array}$ & $\begin{array}{l}\text { Semi-structured } \\
\text { interviews }\end{array}$ & $\begin{array}{l}\text { The visible and invisibility of IDD. } \\
\text { Emotional downturn and impact. Shock } \\
\text { and disappointment. Grief and loss. Denial } \\
\text { and blame. }\end{array}$ & $\begin{array}{l}\text { Healthcare professionals need to } \\
\text { recognize and respond to the distinct } \\
\text { emotional and support needs of } \\
\text { fathers following a diagnosis of IDD. }\end{array}$ \\
\hline
\end{tabular}




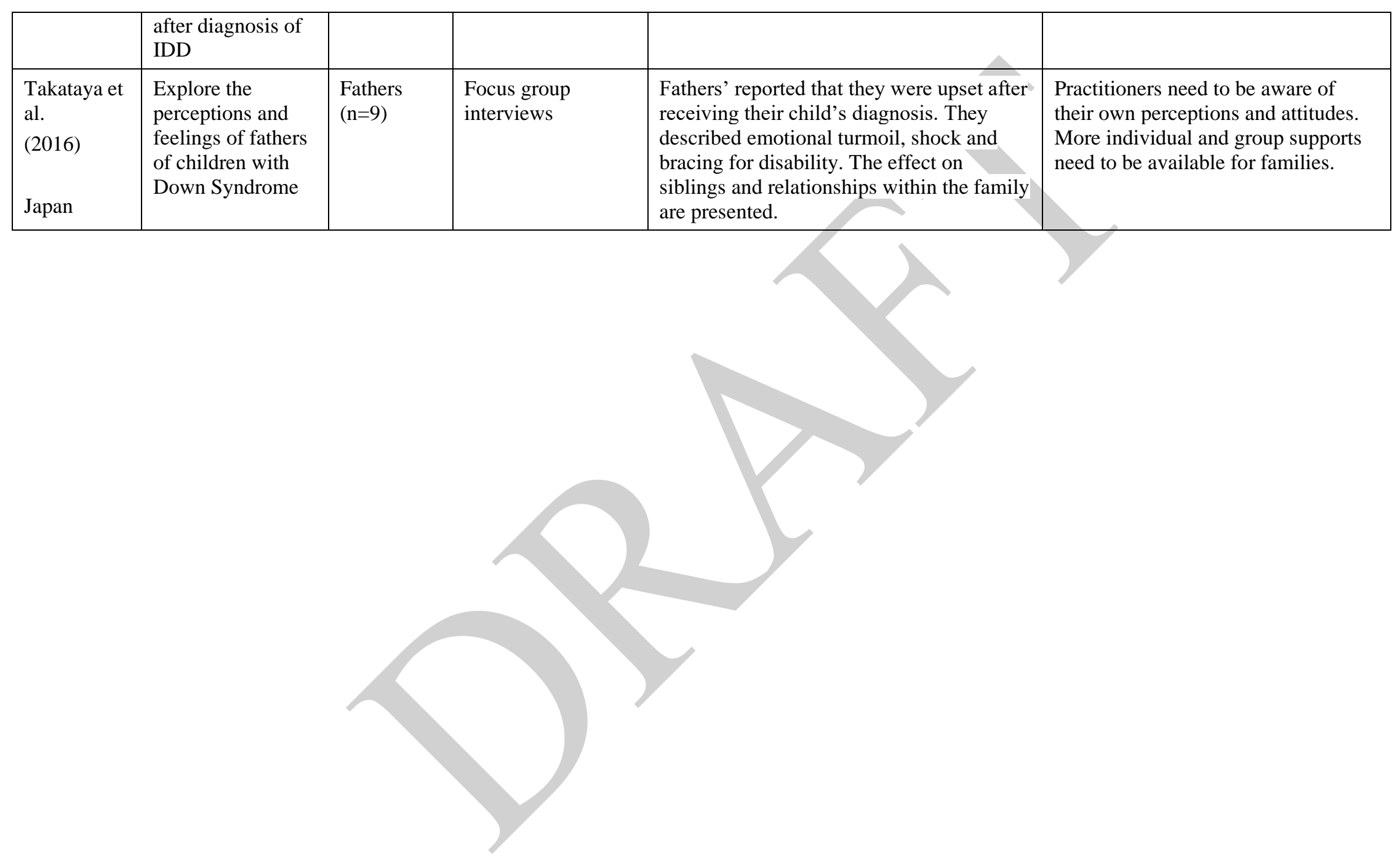


Figure 1: PRISMA flow Diagram with search results

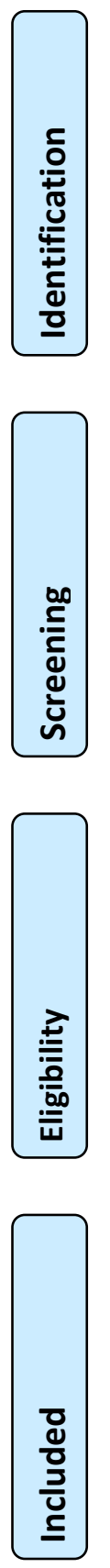

Articles excluded based on abstract review: $(\mathrm{n}=159)$
Studies identified in reference lists: $(\mathrm{n}=1)$
Full-text articles excluded $(n=8)$

$$
\text { ( } \mathrm{n}=21 \text { ) }
$$

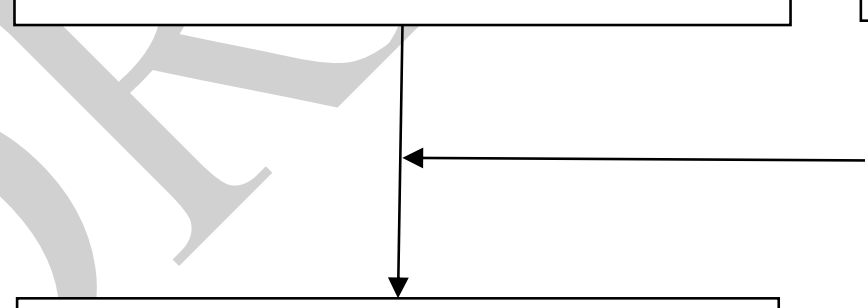

Studies included in synthesis:

$$
(n=14)
$$

